\title{
In situ $\mathrm{Rb} / \mathrm{Sr}$ dating, a precise and efficient tool in metamorphic petrology to constrain Iran geodynamic
}

\author{
THOMAS GYOMLAI ${ }^{1}$, PHILIPPE AGARD ${ }^{2}$, GUILLAUME \\ BONNET $^{1}$, BENOIT CARON ${ }^{2}$, BENOIT DUBACQ ${ }^{2}$ AND \\ JULIE NOEL ${ }^{3}$ \\ ${ }^{1}$ Sorbonne université \\ ${ }^{2}$ Sorbonne Université \\ ${ }^{3}$ sorbonne université \\ Presenting Author: thomas.gyomlai@sorbonne-universite.fr
}

Constraining the age and duration of tectonometamorphic events is a major issue. In-situ dating methods are particularly suitable in this case, allowing the analysis of small phases $(\sim 50$ $\mu \mathrm{m})$ and thus dating of different texturally-resolved generations (linked with distinct P-T conditions) in order to trace the long history recorded in the metamorphic rocks. In-situ $\mathrm{Rb} / \mathrm{Sr}$ dating of mica is particularly attractive because micas are generally abundant in metamorphic rocks. Additionally, the isochrons can be obtained from single populations of micas since $\mathrm{Rb} / \mathrm{Sr}$ ratios of micas are often grain-size dependent.

This study focuses on Central Iran where only few radiochronological data are available. This area has a complex geodynamic context and underwent major tectonometamorphic and magmatic events:

(1) During the Neoproterozoic and Paleozoic, the Iranian tectonic blocks underwent the Pan-African and Cadomian orogeneses before being separated from the Gondwana by the opening of the Neotethys.

(2) During the Mesozoic, these blocks collided with the Eurasian margin thanks to the closure of the Paleotethys, during the multiphase "Cimmerian" orogeny.

(3) A significant reorganization of these blocks took place in the Mesozoic and Paleogene, with the development and closure of several back-arc basins related to the Neotethys subduction.

(4) The closure of the Neotethys, around $30 \mathrm{Ma}$, and the formation of the Zagros completed the structuring of Iran.

We performed a laser ablation $\mathrm{Rb} / \mathrm{Sr}$ dating of micas by online chemical separation of ${ }^{87} \mathrm{Rb}$ and ${ }^{87} \mathrm{Sr}$ in a nitrous oxide filled reaction cell $\mathrm{ORS}^{4}$ between two quadrupoles of a mass spectrometer, using a method adapted from Zack and Holgman (2016). $\mathrm{N}_{2} \mathrm{O}$ is reacting with more than $85 \%$ of the $\mathrm{Sr}$ and does not react with $\mathrm{Rb}$. All analyses were performed at the ALIPP6 lab (ISTeP, Sorbonne Université, Paris) using an Excimer 193 nm Analyte G2 Teledyne laser ablation system with an Agilent 8900 triple-quadrupole ICP-MS/MS coupled with a reaction cell. This method allows to quickly obtain a lot of texturally constrained 'in-situ' ages and therefore to gain insights on the different tectonometamorphic events of Iran. 